\section{${ }_{756}$ \\ 特 集 \\ 1 はじめに \\ ガス流通式反応セルを用いて気相で有機電解合成を行 なうと，反応系に溶媒を必要としないので，反応物およ び生成物の電極界面への拡散および界面からの拡散が容 易となり，反応速度が増大して単流転化率を大きくでき， これらに関連して生成物の分離工程が簡単となるなどの 利点がある。しかし，気相あるいは溶媒中を問わず，電 解合成には高価な電力を投入しなければならないので, 目的生成物の付加価値が高くなければ, 実用的なプロセ スとしては成立し得ない。むし，電解合成が電池反応を 応用して実施できれば，電力を供給する必要がなく，有 用な化合物と共に電力が副産物として得ら㧈る(ケミカ ルコジェネレーション)。また，この電池反応を，ガス 流通式反応セルを用いて気相で実施すれば, 最初に述べ た利点が生きてくる. \\ 筆者らは，上記の考えに沿って，気相燃料電池反応七 ルを用いたアルコールおよび各種炭化水索の部分酸化反 応を実施し，有用な含酸素化合物の合成を試みている。 本稿では, 筆者らの研究例を中心に, 気相電池の有機合 成への応用を紹介する。}

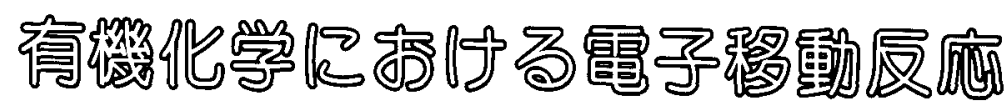

\title{
q 気相電池法による有機合成
}

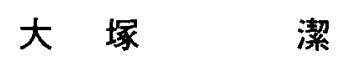

\section{2 メタノール燃料電池からメチラールと ギ酸メチル合成}

天然ガスから大量に合成されている安価なメタノール は, 石油化学工業において, 石油に代わる出発原料とし て注目されている、メタノールを原料とする合成反応は 数多く知られているが, 中でもメ夕ノールとホルムアル デヒドから合成するメチラールおよびメタノールとギ酸 のエステル化で生成するギ酸メチルは, 溶剤として, あ るいは様々な試薬の中間体原料として広い用途がある。

筆者らは, メタノールからメチラールとキ酸メチルを一 段で合成する新しい方法として，Fig. 1 に示した燃料 電池反応システムの応用を提案した ${ }^{1,2)}$. この反応器で は, リン酸水溶液を含ませたシリカウールディスクを両 室の隔膜とし，ディスクの両面に貴金属電極を張り付け

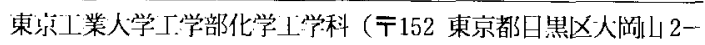
12-1)
ている．左室にメ夕ノール蒸気を，右室に酸素ガスを流 し，画極間を短絡すると，燃料電池の原理でアノード上 でメタノールの酸化が進行して、メチラール，ギ酸メチ ルおよび $\mathrm{CO}_{2}$ が生成する，外部回路に負荷を置けば， 生成物之共に電力が取り出せるが，本反応法の第一義的 な目的は有用化合物の合成にあるので，通常は短絡条件 下で反応を行なうことにしている。

種々の貴金属電極の組合せについて测定した結果を Table 1 に示した，開回路電圧，電流値（電極幾何面 積 $\left.2.5 \mathrm{~cm}^{2}\right)$ 抢よびメチラールとギ酸メチル合計の選択 率を示している，用いた電極はホットプレス法（金属， グラファイトイテフロン $=20 / 50 / 5 \mathrm{mg}$ ) で作成してい る. Table 1 で気付くことは，アノードとカソードに

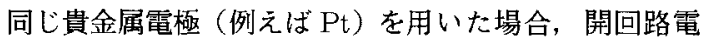
圧と電流密度が著しく小さくなることである。これに対 して，アノード側に Ir，カソード側にこれとは異なる 金属を用いた場合，他の組合せに比較して開回路電圧と

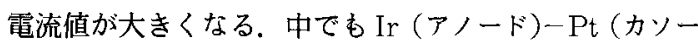
ド）の組合せは，最も大きな開回路電纴之電流値を与元 ている，異なった金属からなる電極の組合せでこのよう な差異が出る原因は, メタノールか隔膜中に溶解しカソー ド側に漏れ出すからである。これはケミカルショートと 呼ばれ, カソード側の酸素の還元反応を阻害したり, 酸 素による触媒的な酸化反応を誘発し, 電生と電流値を著 しく低下させる原因となる. Fig. 1 の反応器のアノー ド室とカソード室に同一組成のメタノールと酸素の混合

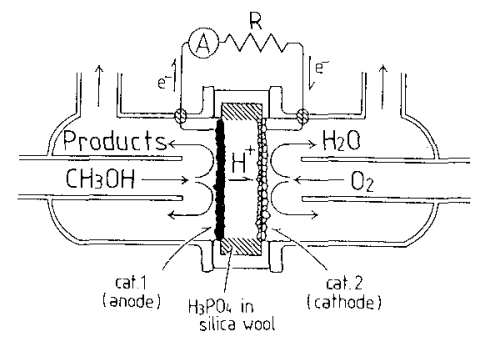

Fig. 1 The gas phase methanol fuel cell for the synthesis of methylal and methyl formate. 
Table 1 Partial oxidation of methanol with various Metal (anode)-Metal (cathode) combination.

\begin{tabular}{ccccc}
\hline Anode & Cathode & $\begin{array}{c}\text { Open } \\
\text { voltage } \\
/ \mathrm{mV}\end{array}$ & $\begin{array}{c}\text { Current } \\
/ \mathrm{mA}\end{array}$ & $\begin{array}{c}\text { Select. }^{\mathrm{a})} \\
/ \%\end{array}$ \\
\hline $\mathrm{Pt}$ & $\mathrm{Pt}$ & 25 & 0.2 & 0 \\
$\mathrm{Pt}$ & $\mathrm{Ir}$ & 51 & 0.3 & 0 \\
$\mathrm{Pt}$ & $\mathrm{Rh}$ & 320 & 4.8 & 37.3 \\
$\mathrm{Ir}$ & $\mathrm{Rh}$ & 615 & 14.0 & 55.5 \\
$\mathrm{Ir}$ & $\mathrm{Pt}$ & 654 & 31.8 & 53.8 \\
$\mathrm{Ir}$ & $\mathrm{Pd}$ & 634 & 8.2 & 61.1 \\
$\mathrm{Ir}$ & $\mathrm{Ru}$ & 620 & 9.2 & 63.9 \\
$\mathrm{Ir}$ & $\mathrm{Ir}$ & 142 & 0.1 & 0 \\
$\mathrm{Rh}$ & $\mathrm{Ir}$ & 20 & 0.1 & 0 \\
$\mathrm{Pd}$ & $\mathrm{Rh}$ & 269 & 1.8 & 47.8 \\
\hline
\end{tabular}

a) Selectivity for partial oxidation of methanol. Reaction conditions:

$$
\text { anode; } \begin{aligned}
\mathrm{P}\left(\mathrm{CH}_{3} \mathrm{OH}\right) & =5.4 \mathrm{kPa} \\
\mathrm{P}\left(\mathrm{H}_{2} \mathrm{O}\right) & =4.2 \mathrm{kPa} \\
\mathrm{F} & =35.9 \mathrm{ml} \cdot \mathrm{min}^{-1} \\
\text { cathode } ; \mathrm{P}\left(\mathrm{O}_{2}\right) & =53 \mathrm{kPa} \\
\mathrm{P}\left(\mathrm{H}_{2} \mathrm{O}\right) & =48 \mathrm{kPa} \\
\mathrm{F} & =38.2 \mathrm{ml} \cdot \mathrm{min}^{-1}
\end{aligned}
$$

ガスを流し，開回路電圧および短絡時の電流值と生成物 の生成速度を测定すると, 完全ヶミカルショート条件下 に扔けるアノードとカソードの状況を把握することがで きる. 結論として，完全ケミカルショート下では，いず れの電極との組合せです, 常に Ir がアノードとなり, 開回路電位は $\mathrm{Ir}<\mathrm{Pt}<\mathrm{Rh}<\mathrm{Ru}<\mathrm{Pd}$ の順番となること が分かった，この結果は, 電気化学的なメタノール酸化 活性は $\mathrm{Ir}$ で最も高く，その序列は $\mathrm{Ir}>\mathrm{Pt}>\mathrm{Rh}>\mathrm{Ru}>$ Pdとなることを示している. Table 1 で， アノードに Irを，カソードにこれとは異なる金属を用いると，ケ ミカルショートがあるにもかかわらず，高い開回路電生 と電流值が得られたのは，Irのメ夕ノールを酸化する 能力が他の金属と比較して著しく高いからである.

次に, 開回路電圧と短絡時の電流值に最も高い値を与

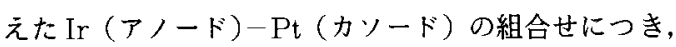
反応速度と選択率におよぼす様々な速度因子を調べ, 反 応の最適条件を探ってみた。例として，Fig. 2 にセル 温度の影響と Fig. 3 にメタール蒸気圧の影響を示し た. Fig. 2 を見ると, 反応温度の上昇とと屯に電流倠 が大きく増加し， $\mathrm{CO}_{2}$ 生成速度がこれと並行して増大 している. 目的の生成物であるメチラール (DMM) と ギ酸メチル (MF) の生成速度は $353 \mathrm{~K}$ 付近で最大とな り，両者合計の選択率も $353 \mathrm{~K}$ 付近で極大となる. 従っ て，反応温度はこの付近に保ち，あまり高温にすること は得策でないことが分かる.Fig. 3 に示したように， メタノール圧を高くすると $\mathrm{CO}_{2}$ の生成速度が減少し，
メチラールとギ酸メチルの生成速度が増大し, 選択率が 80\%まで上昇する，このとき電流值は減少するので，電 力として取り出せる割合の低下は避けられない，反応速 度之選択率は温度とメ夕ノール圧以外に, 水蒸気厈と力 ソード室の酸素圧にも大きな影響を受ける、メチラール とギ酸メチルの生成には, 隔膜が乾燥しない程度に水蒸 気王は低いほど良い，また，酸素王を高くすると，ギ酸 メチルと $\mathrm{CO}_{2}$ の生成速度が増大して電流值が上昇する. ギ酸メチルの選択率は $50 \%$ 程度に保てるので，酸素圧 を高くすると電力とギ酸メチルの同時生産には有利とな る.

Fig. 4 は電極上および隔膜中で起こるメタノール電 池反応を模式的に示した四である ${ }^{3.4)}$. Ir アノード上で
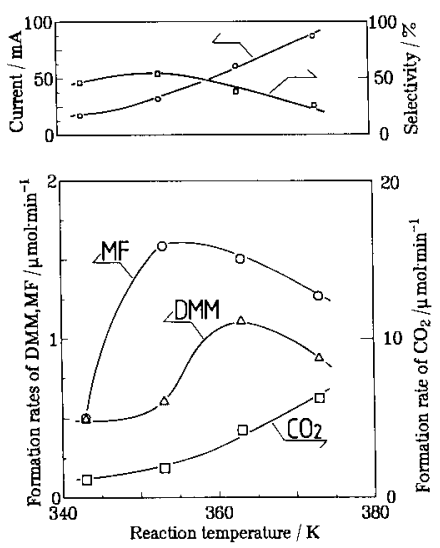

Fig. 2 Effects of temperature on the rates of products, the currents and on the selectivity of the sum of methylal (DMM) and methyl formate (MF). Experimental conditions were same as given in Table 1 .
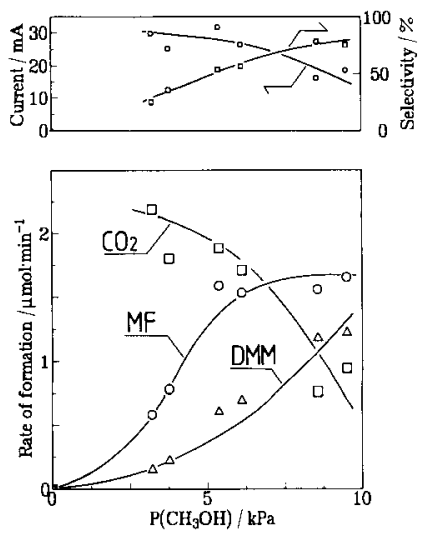

Fig. 3 Effects of methanol pressure. Experimental conditions were same as given in Table 1. 
メタノールが二電子酸化されてホルムアルデヒド中間体 を生成し，このホルムアルデヒド中間体はリン酸の強い 酸触媒作用を受け，メタノールと反応してメチラールに 転換される．このホルムアルデヒド中間体はさらに二電 子酸化されキ酸中間体を生成するが，これも直ちにメ夕 ノールと反応してキ酸メチルに転化する。酸中間体は さらに深く酸化されて $\mathrm{CO}_{2}$ になる. Fig. 3 で見たよう に,メタノール压が高くなると、メチラールとギ酸メチ ルの生成速度が增加し $\mathrm{CO}_{2}$ 生成速度が低下するのは, メタノールに係わるアセタール化反応㧍よびエステル化 反応が $\mathrm{CO}_{2}$ の生成に比較して有利になるためである。

これに対して, 水蒸気圧が増加するとメチラールとキ酸 メチル生成が阻害され， $\mathrm{CO}_{2}$ の生成が促進される。 反 応温度の上昇は膜中のメタノール濃度を低下させるので, メチラールと酸メチルの生成が抑制され, $\mathrm{CO}_{2}$ 生成 が主反応になると考えられる。

以上の知見は，さらに有効な電極触媒の開発，最適反 応条件の設定および反応セルの改良等に有益な情報を与 える.

\section{3 エチレン燃料電池でのアセトアルデヒド合成} 有機合成試薬，香料，プラスチック，可塑剂などの原 料として広い用途のあるアセトアルデヒドは, 塩化パラ

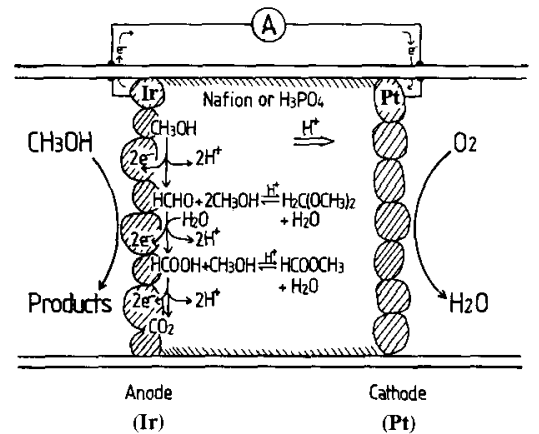

Fig. 4 Reaction profile for the partial oxidation of methanol in the fuel cell.
ジウムと塩化銅を触媒としたワッカー法により，エチレ ンの部分酸化で製造されている。筆者らは, 新規なアセ トアルデヒド合成法として，Fig. 1 と同じ反応器を用 いたエチレン燃料電池反応の応用を試みた。種々の電極 を探索した結果，アノード極にPdを用いた場合にのみ， アセトアルデヒドが極めて選択的に合成できることを見 出した ${ }^{5)}$. Table 2 には, アノードにPd黑電極, カソー ドに Pt 黑電極を用いた場合の結果を示した．温度 373 $\mathrm{K}$, エチレン王 $30 \sim 50 \mathrm{kPa}$, カソードの酸素仕約 95 $\mathrm{kPa}$ 下では, 開回路電压 $0.6 \sim 0.7 \mathrm{~V}$ をえ, 短絡時に は約 $10 \mathrm{~mA} / \mathrm{cm}^{2}$ の電流が流れた。 アセトアルデヒドの 選択率は $97 \%$ 以上と高く, 電極面積が $3.1 \mathrm{~cm}^{2}$ と小さ いにもかかわらず単流アセトアルデヒド収率は $3 \sim 6.5$ \%程度にはなっている. $0.15 \mathrm{~V}$ の電圧を印加すると,

電流効率の低下を伴わず，アセトアルデヒド収率が電流 に比例して增大している，短絡時のアセトアルデヒド生 成速度は，電極幾何面積に比例しカソード側の酸素王に 比例することが分かっているので, 電極面皘と酸素圧を 増大させ反応器のスケールアップを図れば, 実用化レベ ルのアセトアルデヒド生産が気相電池法でも可能になる と思わ扎る。

ワッカー法によるアセトアルデヒド製造では，次のよ うな問題点が指摘されている. (i) 均一系の触媒反応で あるため，水溶液から生成物を分離する必要がある。(ii) 水溶液は強い塩酸酸性を有するので, 腐食に耐える高価 な反沈装置が要求される。(iii) 含塩素化合物が副生する. (iv) エチレンと酸素の混合がスで反応させる場合(へキ スト法）には爆発の危険がある。このような欠点は上述 した気相電池法を用いれば解決でき，実用プロセスとし てもワッカー法より有利になることが予想される.

\section{4 トルェンからのベンズアルデヒド合成}

トルェンの部分酸化で選択的にベンズアルデヒドを合 成することは, 難しい反応の一つとして知られている. 筆者らは, 先に述べたように, エチレンからのアセトア ルデヒドの合成に気相電池法が使えることが分かったの

Table 2 Current density (CD), current efficiency (CE), and the yield of acetaldehyde under optimum conditions.

\begin{tabular}{|c|c|c|c|c|c|c|}
\hline \multirow[b]{2}{*}{$\begin{array}{l}\text { Run } \\
\text { No. }\end{array}$} & \multicolumn{3}{|c|}{ Anode conditions } & \multirow[b]{2}{*}{$\begin{array}{c}\mathrm{Cl}) \\
\left(\mathrm{mA} / \mathrm{cm}^{2}\right)\end{array}$} & \multirow[b]{2}{*}{$\begin{array}{c}\% \mathrm{CE} \\
\mathrm{CH}_{3} \mathrm{CHO}\end{array}$} & \multirow[b]{2}{*}{$\begin{array}{c}\% \mathrm{CH}_{3} \mathrm{CHO} \\
\text { yield }\end{array}$} \\
\hline & $\begin{array}{c}\mathrm{P}\left(\mathrm{H}_{2} \mathrm{O}\right) \\
(\mathrm{kPa}) \\
\end{array}$ & $\begin{array}{c}P\left(\mathrm{C}_{2} \mathrm{H}_{4}\right) \\
\left(\mathrm{k} \Gamma^{\prime} \mathrm{a}\right)\end{array}$ & $\begin{array}{c}\text { Nlow rate } \\
(\mathrm{ml} / \mathrm{min})\end{array}$ & & & \\
\hline 1 & 12 & 49 & 15 & 10.8 & 79 & 2.9 \\
\hline 2 & 16 & 39 & 9 & 9.1 & 74 & 4.8 \\
\hline 3 & 16 & 29 & 9 & 9.0 & 82 & 6.5 \\
\hline \multicolumn{7}{|c|}{ (Lnder $0.15 \mathrm{~V}$ applied potential) } \\
\hline 4 & 17 & 30 & 9 & 15.1 & 82 & 10.8 \\
\hline
\end{tabular}

Experimental conditions: Anode-Pd-black $(20 \mathrm{mg})$. Cathode-Pt-black $(40 \mathrm{mg}) . \mathrm{P}\left(\mathrm{O}_{2}\right)=93-100 \mathrm{kFa}$, flow rate of $\mathrm{O}_{2}=30 \mathrm{ml} / \mathrm{min}$, area of electrode $=3.1 \mathrm{~cm}^{2}$, and temperature $=373 \mathrm{~K}$. 
で，トルエンからのベンズアルデヒド合成にも応用を試 みた ${ }^{6)}$

各種アノード触媒をテストした結果，エチレンの場合 と同様にPd黑が有効であることが分かった。しかし，

$\mathrm{Pd}$ 黒だけでは，ベンズアルデヒド選択率は $50 \%$ 以上に ならず，電流值もエチレン酸化と比較すると著しく低い あのであった．Pd黒にアルカリまたはアルカリ土類塩 化物を添加すると， $\mathrm{CO}_{2}$ の生成が著しく抑制され，心゙ ンズアルデヒド生成は促進されることが分かった。この ような塩化物の添加効果は, 特に $\mathrm{NaCl} て ゙$ 著しく認め られだ．

反岕は, Fig. 5 に示すように, トルェンと $\mathrm{Pd}^{2+}$ 塩化 物間に生成した錯体を中間体として進行すると推論して いる ${ }^{6} . \mathrm{NaCl}$ の添加は $\mathrm{Pd}^{2+}$ 錯体の生成を促進させる. この錯体はリン酸膜中に溶解し, 非電気化学反応で (2), (3) および(4)の過程を経て生成物を与える.この証拠は, 回路を開いた後む長時間ベンズアルデヒドの生成が観測 される事実と, 生成物合計の電流効率は開回路後の生成 物む加えないと $100 \%$ から大きくはずれてしまうことに ある. Fig. 5 の反応機構のくわしい説明は文献 6）を参 照してほしい。

\section{$5 \quad \mathrm{H}_{2}-\mathrm{O}_{2}$ 燃料電池反応中のベンゼン水酸化}

Fig. 1 の反応器のアノード室にメタノールの代わり にベンゼン蒸気を流し，Pt，Pd 等の活性な金属電極を 用いたアノード上でのベンゼン酸化を試みたが， $373 \mathrm{~K}$ 以下では反応が起こらなかった。 さらに温度を上げると, ベンゼン酸化は起こるようになるものの, 生成物は $\mathrm{CO}_{2}$ だけであり，フェノールなどの部分酸化生成物は生成し なかった。そここで，発想を变えて，ベンゼン側には酸素

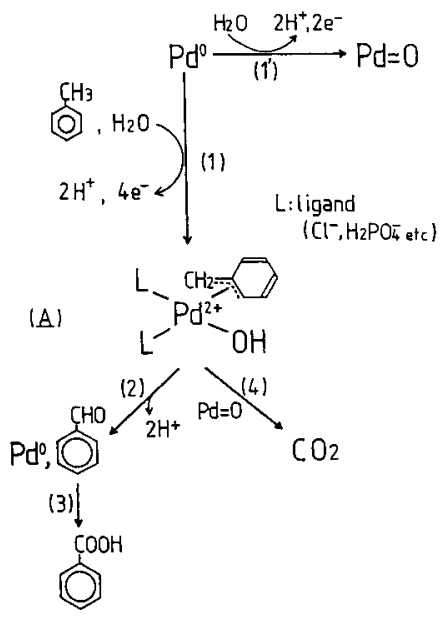

Fig. 5 Reaction scheme for the partial oxidation of toluene in the toluene fuel cell.
あ同時に流し，対極室に酸素の代わりに水素を流したと ころ, $353 \mathrm{~K}$ 以下の温度です, 多くの電極上でフェノー ルの生成がほぼ $100 \%$ の選択率で進行するようになっ た 7 10). この場合, ベンゼンの酸化はカソード上で進行 することになる。ベンゼン以外にあ，温和な条件では困 難と言わ机るアルカンやアロマの部分酸化が，室温付近 の温度で進行することを確かめている ${ }^{711)}$ 。このような 難しい反応がカソード上で進行するようになるのは，次 式に示すように，カソード上で $\mathrm{O}_{2}$ が還元的に活性化さ れ，活性酸素種 O*を発生させ，このO*が基質を直接 酸化するからである。

$$
\begin{aligned}
& \mathrm{O}_{2}+2 \mathrm{H}^{+}+2 \mathrm{e}^{-} \longrightarrow \mathrm{H}_{2} \mathrm{O}+\mathrm{O}^{*} \\
& \mathrm{O}^{*}+\mathrm{C}_{6} \mathrm{H}_{6} \longrightarrow \mathrm{C}_{6} \mathrm{H}_{5} \mathrm{OH}
\end{aligned}
$$

気相ベンゼンの水酸化反応に実際に用いた反応器は, リン酸水溶液が流通できるようになっており，水溶液中 に溶解したフェノールは常時系外に取り出し定量分析を している. 気相系の反応においては，カーボンウィスカー を熱硝酸で処理して活性化したカソード電極が比較的高 い活性を示した。主生成物はつェノールとヒドロキノン であり， $\mathrm{CO}_{2}$ の生成は全く認められなかった，例とし て，両電極間を短絡した場合に進行するフェノールとヒ ドロキノン生成の経時変化を Fig. 6 に示す．両者共に 生成量が反応時間の経過と共に直線的に増大し，カソ一 ド上でのベンゼン水酸化反応が定常的に進行することが 分かる ${ }^{12)}$.

上述の反応システムでは， $\mathrm{H}_{2}-\mathrm{O}_{2}$ の燃料電池反応が 主に起きて水が生成するので, フェノール生成の電流効 率は通常 $10 \%$ 程度である。この場合には, 電力の副産

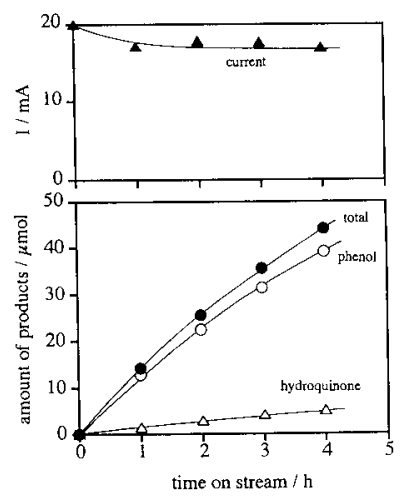

Fig. 6 The oxidation of benzene to phenol and hydroquinone in the gas phase as functions of time on stream under short circuit conditions. Under standard reaction conditions : $\mathrm{T}=353 \mathrm{~K}$. Cathode of carbon whisker, $\mathrm{P}\left(\mathrm{C}_{6} \mathrm{H}_{6}\right)=64 \mathrm{kPa}$, $\mathrm{P}\left(\mathrm{O}_{2}\right)=37 \mathrm{kPa}$. Anode of $\mathrm{Pt}$-black/graphite, $\mathrm{P}\left(\mathrm{H}_{2}\right)=50 \mathrm{kPa}$. 
物として有用な含酸素化合物の生成を位置付けるべきか あ知れない，カソード触媒の改良でケミカルズ生成の効 率を向上させ，フェノールなどよりもっと付加価值の高 い生成物を対象とすれば，本方法の応用む現実味を帯び てくるものと思われる.

\section{6 おわに}

以上，気相電池を応用した酸素付加反応を例に，電力 を投入しないで行なう有機電解合成法の可能性と特徵の 一端を述べた. 目的生成物の選択率では満足すべきもの もあるが，反応速度あるいは電流密度においてはまだま だ十分なレベルに達していない，電池反応を応用した部 分酸化法の最大の課題は, 部分酸化の選択率を低下させ ずにどこまで電流密度を高めることができるかにある. 完全酸化して $\mathrm{CO}_{2}$ にまですれば, $-\Delta \mathrm{G}$ と電池電圧が 大きくなり電流密度は上がる．部分酸化の選択率と電 流密度とは互に二律背反する側面を持っているので, 雨 者を同時に高めることは常識的には大变困難が伴うと思 われる.ターゲットとする反応の選択, 新たな発想に立っ た電極触媒の創成, セルの工学的最適化, 電解質の選択 と電気的特性の向上, 最適反応条件の探索などを積極的 に進めることて，気相電池法による有機合成を現実なる
のとすることは筆者の夢でもある.

\section{文献}

1) I. Yamanaka and K. Otsuka, Chem. Lett., 753 (1988).

2）大塚 潔，止奈智秀，山中一郎，日化第 63 春李年会， 1 C 348 (1992).

3) K. Otsuka and I. Yamanaka, Appl. Catal., 26, 401 (1986)

4）大塚 潔，山中一郎，表面，27，473 (1989).

5) K. Otsuka, Y. Shimizu and I. Yamanaka, J. Electrochem. Soc., 137, 2076 (1990).

6) K. Otsuka, K. Ishizuka, I. Yamanaka and M. Hatano, J. Electrochem. Soc., 138, 3176 (1991).

7) K. Otsuka, I. Yamanaka and K. Hosokawa, Nature (London), 345, 697 (1990).

8) I. Yamanaka and K. Otsuka, J. Electrochem. Soc., 138, 1033 (1991)

9) K. Otsuka, M. Kunieda and H. Yamagata, J. Electrochem. Soc., 139, 2381 (1992).

10) I. Yamanaka and K. Otsuka, J. Chem. Soc., Faraday Trans., 90, 451 (1994).

11) I. Yamanaka and K. Otsuka, J. Chem. Soc., Faraday Trans., 89, 1791 (1993)

12) 1. Yamanaka, T. Akimoto and K. Otsuka, Electrochim. Acta, in press.

\section{2 光増感一電子酸化による $\mathrm{C}-\mathrm{C}$ 結合の 開裂とその後続反応の制御}

\section{1 はじめに}

光により誘起される電子移動は, 有機合成の観点から あ重要であるが, 光機能性材料の開発や光合成機構の解 明といった面からも注目されている1．光誘起電子移動 反応は，電極反応や酸化剂・還元剤による電子移動反応 之同様に，基質の一電子酸化・還元に上り発生するラジ カルイオンを活性種とする反応である. しかし, 励起状 態の分子（増感剂）を電子供与・受容体とすることから, 以下の様な他の系にはない特徽を持つ。

(1) 光誘起電子移動は可逆プロセスであり, 逆電子移 動過程が存在する，逆電子移動は，ラジカルイオン中間 体の寿命を制限し, 反応効率の滅少の直接的な原因とな る、また，光増感反応はパルス・レーザーを用いた過渡 吸収測定により短寿命中間体を観測するのに適している

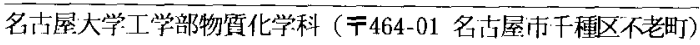

石 黒勝 也, 沢木泰 彦*

が、ラジカルイオンの反応を追跡するためには，逆電子 移動よりも速いことが要求される.

(2)一光子により誘起される電子移動は基本的に一電 子過程である. 電極反応などの様に二電子あるいはそれ 以上の多電子移動か関与することはまれである. 従って, 発生するラジカル中間体をあう一電子酸化・還元してイ オン種へ変換することができないため, 安定生成物を得 るには後続反応の制御が必要となる.

(3) 電子移動によりラジカル中間体がイオン対となっ て発生する. そのため, ラジカルカチオンとアニオンの 間の反応といった, 電極反応では起こり得ない反応も可 能となる。

(4) 系外との電子の授受がなく, 系全体では電子の収 支が保たれている，従って，酸化之還元が常に同時に起 こる. 条件を適切に選べば，発生した中間体と增感剂ラ ジカルイオンの間の逆電子移動により，増感剂を光触媒 